\author{
Jerzy Stefan Ossowski* \\ Uniwersytet Jana Kochanowskiego w Kielcach \\ https://orcid.org/0000-0002-3039-3939
}

\title{
Światy Gałczyńskiego
}

Streszczenie: W roku 1937 ukazały się Utwory poetyckie Konstantego Ildefonsa Gałczyńskiego. W dyskusji o tym tomie wierszy głos zabrali pisarze: Witold Gombrowicz i Józef Czechowicz oraz krytycy: Bolesław Miciński, Stefan Lichański, Kazimierz Wyka. Wszyscy dowodzili, że na tle polskiej poezji Dwudziestolecia twórczość Gałczyńskiego stanowi zjawisko niezwykłe, oryginalne. Autor artykułu skonfrontował oceny wspomnianych znawców literatury z opiniami badaczy współczesnych, którzy te oceny potwierdzili oraz ugruntowali hermeneutycznie (Andrzej Lam, Adam Kulawik). Wyciągnął z tych werdyktów wnioski aksjologiczne i postawił tezę, że wiersze oraz poematy metafizyczne Gałczyńskiego mogą być uznane za reprezentatywne dla polskiej poezji XX wieku. Rezultaty ideowo-artystycznej analizy tych poematów (Bal u Salomona) i wierszy (Serwus, Madonna), dowodzą, że ideologia, cenzura oraz krytyka - które były na usługach państwa komunistycznego - zniekształciły recepcję i interpretację liryki Gałczyńskiego. W poezji europejskiej poemat Gałczyńskiego, Bal u Salomona, i jego liryka metafizyczna - powinny zająć

Jerzy Stefan Ossowski - dr hab., prof. Uniwersytetu Jana Kochanowskiego w Kielcach. Ważniejsze książki: Szarlatanów nikt nie kocha. Studia i szkice o Gałczyńskim (Kraków 2006) oraz Sprawa Gałczyńskiego. Szkice z antropologii kultury literackiej (Kielce 2011). 
to miejsce, jakie zajęła katastroficzna i metafizyczna poezja Thomasa Stearnsa Eliota.

Słowa-klucze: K. I. Gałczyński, T. S. Eliot, katastrofizm, poezja metafizyczna, recepcja, interpretacja.

\section{Galczynski's Worlds}

Summary: In the year 1937, Konstanty Ildefons Gałczyński's “Utwory poetyckie" [Poems] were published. The writers: Witold Gombrowicz, Józef Czechowicz and critics: Bolesław Miciński, Stefan Lichański and Kazimierz Wyka discussed these poems and their importance. They all agreed with and argued that in the context of the Polish poetry of the Twentieth Century, Gałczyński's work is an extraordinary, original phenomenon. The author of the article confronted the assessments of the aforementioned scholars with the opinions of contemporary researchers (Andrzej Lam, Adam Kulawik) who agreed with the previous opinions. The author drew axiological conclusions from these verdicts and put forward a thesis that Gałczyński's poetic works could be considered representative for the 20th century Polish poetry. The results of the ideological-artistic analysis of these poems ("Bal u Salomona", "Serwus, Madonna") prove that ideology, censorship and criticism - all of them serving the communist regime - distorted the reception and interpretations of Gałczyński's poems. In the European poetry, Gałczyński's metaphysical poetry and his poem "Bal u Salomona" deserves the same place as Thomas Stearns Eliot's catastrophic and metaphysical works.

Key words: K. I. Gałczyński, T. S. Eliot, catastrophism, metaphysical poetry, reception, interpretation.

\section{I}

Od słynnych rozważań Arystotelesa w Poetyce, że poezja jest bardziej filozoficzna, niż historiozofia, aż po współczesną Heideggerowską apologię poezji, która kroczy „,w prawdzie” z filozofią - w większości współczesnych kierunków humanistyki i estetyki panuje przekonanie, że sztuka poetycka służy 
odsłanianiu, objawianiu oraz prezentacji prawdy, dobra i piękna, a więc wartości, jakich - bez jej pomocy - nie bylibyśmy w stanie doświadczyć ${ }^{1}$. Szczególną rolę w odkrywaniu tych wartości artystyczno-estetycznych, autotelicznych, przejaśnianiu skrywającego się bycia, odsłanianiu najgłębszej prawdy o istnieniu - pełni poezja Konstantego Ildefonsa Gałczyńskiego - swoje szczyty osiągająca w objawianiu jakości metafizycznych. Odtwarzanie i wyrażanie sensu istnienia, bycia, a więc fundamentalnych jakości metafizycznych sprawia, że genialna liryka Gałczyńskiego zdolna jest wzruszać, zachwycać, wstrząsać zwracając się ku temu, co „inne”, co „poza”, co „gdzie indziej”.

Co więcej, cała liryczna twórczość poety w znacznym stopniu obejmuje tematy, motywy i rozważania nad byciem i czasem (historią), złem i dobrem, miłością i śmiercią, więc przedstawia świat w sąsiedztwie nieuchwytnych zaświatów, z jakich do czytelników płyną metafizyczne ,impulsy” emocjonalne i intelektualne. Warto zatem pochylić się nad wierszami Gałczyńskiego, dostrzegając $\mathrm{w}$ nich obszary związane z przygodnością, kruchością, niewyrażalnością, nieuchwytnością istnienia, kiedy niedookreślone bycie podlega jakimś przerastającym je potęgom metafizycznym bądź transcendentnym, które rozstrzygają o sensie egzystencji człowieka.

Gałczyński jako autor Utworów poetyckich (1937) - które przede wszystkim tutaj będą analizowane, a także opisywane - to poetycki eksperymentator i krytyk kształtu cywilizacji XX wieku, „organizator wyobraźni narodowej”, lecz przy tym poeta metafizyczny, a jako autor - Modlitwy do Anioła Stróża, czy Serwus, Madonna - poeta religijny, rozporządzający doświadczeniem wywoływanym tym, co niewidzialne, tajemnicze, irracjonalne. Poeta w swoim myśleniu i wyobraźni nieobawiający się rozpoznawania, rozjaśniania tajemnicy bycia, istnienia - mówienia o nich za pomocą mitów, alegorii, symboli².

Różnorodne mity, symbole, tropy, dygresje, aluzje kulturowe i intertekstualne stwarzają $\mathrm{w}$ interesujących nas metafizycznych wierszach i poematach

1 W. Stróżewski, O metafizyczności w sztuce, [w:] Wokół piękna. Szkice z estetyki, Kraków 2002, s. 96-117.

2 W monografii E. Sołtys-Lewandowskiej, O „ocalajacej nieporządek rzeczy” polskiej poezji metafizycznej i religijnej drugiej polowy XX wieku i początków XXI wieku, Kraków 2015 oraz w pracy zbiorowej, Ślady, zerwania, powroty. Metafizyka i religia $w$ literaturze współczesnej, red. E. Sołtys-Lewandowska, Kraków 2015 - nazwisko Gałczyńskiego w ogóle nie pojawia się. 
aurę nieokreśloności, tajemnicy - równocześnie kładąc podwaliny pod poetykę „objawiania się”, poetykę epifanii, która stanowi o wyjątkowej wieloznaczności oraz otwartości dzieła Gałczyńskiego, domagającego się szczególnej starannej recepcji, konkretyzacji i interpretacji odbiorcy ${ }^{3}$.

\section{II}

Pod wrażeniem pomieszczonych w Utworach poetyckich „lekkich i lotnych" wierszy Gałczyńskiego, Witold Gombrowicz nie zawahał się nazwać ich: „czarującymi, zachwycającymi i, co najważniejsze, stuprocentowo rasowymi”4. Dodawał przy tym, że ta „księżycowa, kocia i cygańska poezja jest wspaniała”, gdyż lokuje się w niej „silna dawka prozy, anegdoty, psychologii, nawet polityki - tak zresztą stopionych z poezją w całość organiczną, że świadczy to jeszcze raz o dogłębnej rasowości autora”, który, dzięki „nonszalancji i mistyfikacji [...], bierze czytelnika za nos i zadziera mu twarz do księżyca - puszcza mu w sam nos bańki mydlane - daje mu prztyczki w nos" ${ }^{\text {" }}$. Ten naczelny proceder artystycznego „uelastyczniania słowa”, oparty na „lekkości, barwności i swobodzie pióra”, poeta wyzyskuje, aby zrzucać zbyt obfite ciężary „obowiązków, kanonów i zasad” nakładanych na poezję współczesną ${ }^{6}$. Określenie poezja „księżycowa” odnosić by zatem należało do „silnej dawki” metafizyki.

Kazimierz Wyka nie miał wątpliwości, kiedy w recenzji Utworów poetyckich stwierdzat:

Najbardziej zaś Gałczyński przypomina Ferdydurke Gombrowicza. [...] Gałczyński pierwszy począł eksploatować pokłady infantylnej fantastyki słownej, na której leży Ferdydurke. Podobna u obu pisarzy skłonność do kpiny, do autosatyry [...], do wodzenia po manowcach czytelnika - niestety, zbyt często połączona

3 B. Pawłowska-Jądrzyk, Uczta pod wiszaca skała. Metafizyczność i nieokreśloność w sztuce (nie tylko) literackiej, Warszawa 2011, s. 10-15, passim.

4 W. Gombrowicz, Uwagi dyletanta [prwd. „Ateneum” 1938, nr 2], [w:] Proza (Fragmenty). Reportaże. Krytyka literacka 1933-1939. Dzieła. T. XII. Varia, red. J. Błoński, J. Jarzębski, Kraków 1995, s. 356.

5 Tamże, s. 357-359.

6 Tamże, s. 359. 
z wodzeniem własnego talentu. Przez ironiczne finty zamykające Koniec świata i Ferdydurke przebiega nić wspólności, którą pierwszy Gałczyński wić począł7.

Dopowiedzmy, że u Gałczyńskiego eksploatowanie pokładów infantylnej fantastyki słownej, groteskowo-satyrycznej, ,,wodzenie po manowcach” czytelników opierało się na równoczesnym współudziale rzeczywistości i nierzeczywistości, tego, co realne i tego, co - w świecie przedstawianym fikcyjne. Na podobnych groteskowych fantazmatach Gombrowicz skonstruowal Ferdydurke. I jeszcze jedno warto dodać: dzieła Gałczyńskiego i Gombrowicza były ironiczno-groteskowymi zwierciadłami współczesnej kultury literackiej - banalnej, jałowej, wydrążonej z wartości metafizycznych.

To, co wedle Gombrowicza było artystycznym atutem pisarstwa Gałczyńskiego, dla Wyki okazywało się usterką nie do naprawienia. W cytowanej recenzji Utworów poetyckich, znacząco zatytułowanej Poeta i partyjnictwo, krytyk bronił autonomii twórczej Gałczyńskiego przed literackim partyjnictwem, ale równocześnie zgłaszał uwagi krytyczne na temat jego nonszalancji artystycznej, jarmarcznych refrenów i wiary w automatyzm wzruszeń ${ }^{8}$. Po reprymendzie następowały jednak słowa uznania dla „najbardziej wzruszającego cygana liryki polskiej” i słowa podziwu dla jego oryginalności, samoistności, dla „,zystej poetyckości”, która miała zadośćuczynić fałszywym interpretacjom, promującym Gałczyńskiego na sztandarowego poetę idei „Prosto z Mostu”.

Poszukiwania w liryce Gałczyńskiego duchowych filiacji - zadziwiającego spojenia liryzmu z fantastyką, a fantastyki z nonszalancją - doprowadziły Kazimierza Wykę do źródeł symbolizmu francuskiego, do dekadentyzmu Julesa Laforgue'a oraz prostoty wzruszeń religijnych Paula Varlaine’a. Wskazanie na autora La bonne chanson zawierało sugestię związków „cygana poezji polskiej” z liryką metafizyczną o rodowodzie personalistycznym.

Po odkryciu śladów pokrewieństwa Gałczyńskiego z dekadentyzmem Wyka podjął bardzo ciekawą kwestię: „Dlatego na tle obecnej liryki Gałczyński jest tak inny i sam" - i odpowiedział - [ponieważ - J.S.O.] przeskakując s. 75 .

K. Wyka, Poeta i partyjnictwo, [w:] Rzecz wyobraźni, wyd. II rozsz., Warszawa 1977,

8 Tamże, s. 75-76.

9 Tamże, s. 72-81. 
poezję powojenną jest prekursorem szeregu tendencji, jakie wyróżniają najmłodszych poetów"10. Sygnalizując pewną bliskość źródeł eschatologicznych autora Końca świata z wizyjnymi utworami Józefa Łobodowskiego i Jerzego Zagórskiego - podsumował: „Poezja Gałczyńskiego jest tak bardzo własna, tak do nikogo niepodobna dzisiaj, że sam kontrast wobec przodowników chóru młodych najlepiej wyznacza jej wagę, a poetę wynosi do godności jednego z najpierwszych przodowników tego chóru"11.

Najzdolniejszy uczeń Wyki, wybitny znawca poezji XX wieku, Jerzy Kwiatkowski, w Literaturze Dwudziestolecia zwrócił uwagę na osobny, jak go opisywał - fantastyczno-renesansowy i barokowy, humorystyczno-błazeński, anielsko-muzyczny - świat wyobraźni Gałczyńskiego, swoiście połączony z ideałami prostoty $i$ harmonii, wywiedzionymi z ducha antyku oraz renesan$\mathrm{su}^{12}$. Wspomniał także, iż mimo żartobliwie-zabawowego nastroju, późniejsze - utrzymane w poetyce wizji i swobodnych skojarzeń - utwory Gałczyńskiego ewokują grozę nadchodzących wielkich kataklizmów o uniwersalnym zasię$\mathrm{gu}^{13}$. Niejasne, tajemnicze, wieloznaczne, katastroficzne wizje Gałczyńskiego konkludował - stanowiły zjawisko paralelne w stosunku do patetycznego wizjoneryzmu ówczesnych katastrofistów. W podrozdziale o Wizjonerystach drugiego pokolenia, tudzież patronującym im Józefie Czechowiczu oraz włączonych do tego nurtu żagarystach - Kwiatkowski w ogóle pominął Gałczyńskiego ${ }^{14}$. Za całą deskrypcję dzieła poety uznał bowiem wcześniej wypowiedziane zdanie, że „świetnie zorganizowany artystycznie” Bal u Salomona „samą strukturą poematu” sygnalizuje „zbliżający się rozpad świata”"15. Dopowiedzieć dzisiaj należy, iż eschatologiczny wizjoneryzm Gałczyńskiego w wielu punktach koresponduje z Heideggerowską koncepcją „marnego czasu" ludzkości w końcowym okresie jej historii oraz ideą egzystencji człowieka jako bycia-ku-śmierci.

10 Tamże, s. 74.

11 Tamże, s. 77.

12 J. Kwiatkowski, Literatura Dwudziestolecia, Warszawa 1990, s. 98-99.

13 Tamże, s. 143.

14 Tamże, s. 154-160.

15 Tamże, s. 144. 
Pierwsze intuicje oraz spostrzeżenia krytycznoliterackie na temat wątków metafizycznych w dziele Gałczyńskiego nie doczekały się rozwinięcia i interpretacyjnego ugruntowania, aczkolwiek ich obecność stanowiła tytuł do chwały. Być może z tego względu, że poezja metafizyczna wymaga interpretacji w kategoriach fenomenologii egzystencjalnej (bytu transcendentnego).

\section{III}

Adam Kulawik biegle dowodzi, że katastroficzny Bal u Salomona to arcydzieło liryki Dwudziestolecia ${ }^{16}$. Ten najwybitniejszy poemat $\mathrm{w}$ dorobku Gałczyńskiego, zdający „sprawę z koszmaru egzystencji w niezrozumiałym świecie", mówi o tym, że Bóg-Salomon zgotował ludziom-Hiobom tragicznie przeżywany bezsens, i z tego bezsensu wynikający koszmar ${ }^{17}$. Rozumiejąc intencje $\mathrm{w}$ ten sposób sformułowanej hipotezy całości utworu, pośrednio wywiedzionej bardziej z agnostycznego egzystencjalizmu francuskiego niż $\mathrm{z}$ antropologii biblijnej, nie mogę zgodzić się na przedstawienie relacji Salomon (utożsamiony z Bogiem) - Master of Revels (utożsamiony z Szatanem) jako zmodyfikowanej relacji Jahwe - Szatan z Księgi Hioba. Zdaniem interpretatora nie tylko podmiot liryczny poematu staje się Hiobem, lecz Gałczyński „,przedstawia gatunek ludzki jako Hioba, oczywiście ze szczególnym uwzględnieniem siebie"18.

W snuciu tych podobieństw są pewne - by użyć wyrażenia samego egzegety - „luzy interpretacyjne”, wynikające z tego, że już na początku poematu Bóg zajmuje należne sobie miejsce wśród ludzi:

Klimat? mróz wtedy był trzaskający, jedna z tych chwil przelotnych, gdy Bóg jest siny od chłodu,

16 Zob. A. Kulawik, „Bal u Salomona” - próba określenia wrażliwości poetyckiej Gatczyńskiego, „Poezja” 1973, nr 12, s. 14; tenże, Bal i arkadia - dwa kluczowe motywy liryki K. I. Gałczyńskiego, „Przegląd Humanistyczny” 1974, nr 6, s. 61 i 67 oraz tenże, Poezja to jest złoty szerszeń. Rzecz o poematach K. I. Gałczyńskiego, Kraków 2015, s. 55. W dwu pierwszych studiach badacz podkreślał, że przyczyną zdefektowania, zła świata jest brak elementu transcendentnego, a to oznacza brak odniesienia do wartości ludzkich, dlatego człowiek nie wie nawet, dlaczego cierpi, jaki sens ma jego cierpienie, zagubienie, osamotnienie? W studium ostatnim winą za złą dolę człowieczą autor obarczył Boga.

17 Tamże, s. 64 i 69.

18 Tamże, s. 67. 
a czasem w paszczę kominków przemienia swe niezmierzone ciało i przed paszczami kominków siedziały żony, ojcowie, dzieci, tuż przed paszczami. Może i księgi wtedy czytali spokojni studenci, stojąc, pełne spokojnych kart w złotej cytrynie światła i światło - miłość przedmiotów - płynęło sokiem zachwytu, napływającym do głowy.

Ach błękit, ach mszalne dociekania, ach to, co się czepia brzóz... ${ }^{19}$.

Bóg jako strażnik domowego ogniska nie akceptuje zła na świecie. Zaproponowane przez Kulawika wcielenie Stwórcy w postać Salomona, który nie okazuje dobroci i sprawiedliwości ludziom, wobec czego skazuje ich na cierpnie, ani nie odpowiada logice kontekstu trafnie tłumaczącego intencje autora poematu, ani prawdzie Księgi Hioba ${ }^{20}$. Ten sposób argumentowania istnienia zła na świecie, które akceptuje Bóg, zupełnie abstrahuje od postaci Księcia Nonsensu, a więc Szatana. Poeta przeczuwa jego obecność w tę noc, kiedy zasiadł do tworzenia poematu, wiedząc, że Szatan starał się będzie zagrodzić mu drogę do poznania prawdy o świecie, że będzie próbował pokrzyżować jego projekty twórcze. Jeśli ulegnie pokusie pisania kłamstw, sam skaże się na piekielne udręki, sam odejdzie w „otchłanie absolutnego zwątpienia”, stanie się nihilistą, innymi słowy kimś, kto żyje w stanie ostatecznego samowykluczenia z jedności z Bogiem.

Aliści poeta nie zamierza wyeliminować sacrum ze swojego życia, ani tego, co metafizyczne w poezji, więc zaręcza: „Ale ja zawsze wierzyłem, że człowiek/ choć raz może się zakręcić jak niebo/ i dłużej niż na sekundę". Nie traci więc nadziei, że pomimo innych ,piekielnych” trudności (,muszę być po prostu chory/ bo mam dużo wódki w sercu”) uda mu się przejść z pier-

19 Wszystkie cytowania Balu u Salomona i innych utworów pisarza wg: K. I. Gałczyński, Wybór poezji, oprac. M. Wyka, wyd. VI zmienione, Kraków 2003.

20 Hiob pomimo wielu niezawinionych cierpień nie traci zaufania do Boga, choć nie wie, jak pogodzić Jego sprawiedliwość i dobroć z nieszczęściami, których doświadczył. Dochowując wierności Bogu - Hiob wierzy, że Stwórca wystąpi w obronie jego niewinności, i dzięki swej wierności odzyskuje utraconą pomyślność. Zob. J. S. Synowiec, Mędrcy Izraela, ich pisma i nauka, Kraków 1990, s. 125-135. 
wotnej fazy twórczego procesu pisania poematu o balu u Salomona (co „chodzi za nim od lat trzynastu") do fazy ostrego oświetlenia wybranych starannie absurdów, zaczerpniętych z doznań bądź sytuacji powszednich berlińskiej i europejskiej rzeczywistości lat trzydziestych XX wieku.

\section{IV}

Artystyczne ujęcie natłoku sprzecznych, nieustannie powracających w coraz to innych wariantach treści, wątków, głosów, wymagało jakiejś formy polifonicznej, zbliżonej do muzycznej fugi, w której krótkie tematy kilkakrotnie przeprowadza się przez poszczególne głosy w tej samej, lub innej tonacji, na tle głosów pozostałych. Bal u Salomona wymagał zatem stworzenia takiej poematowej fugi. Bolesław Miciński pierwszy zwrócił uwagę, że cała poezja Gałczyńskiego powstała z ducha muzyki. Poeta zamyka „cierpienie w rytmie pogodnego menueta" $\mathrm{i}$ - podobnie do Mozarta czy Musseta - „uśmiecha się dla wyrażenia bólu”; zaś takie przestawienie znaków uczuciowych sprawia, iż „spoza uśmiechu bufona i ironisty wyłania się otchłań smutku, cierpienia i troski”21. „Wstępne partie Balu u Salomona - zauważa Miciński - można zestawić z Wielkim testamentem Villona"22.

Odwoływanie się do kręgu wyobrażeń i sytuacji egzystencjalnych wyrażanych w innych utworach Gałczyńskiego, które również cechuje „fanatyczna, dickensowska miłość świata" - pozwoliło Micińskiemu trafnie rozszyfrować intencje Balu u Salomona, utworu chwilami przeraźliwie smutnego, chwilami zamkniętego w kręgu Ecclesiastycznym, lecz niepesymistycznego - bowiem-podkreślał-uśmi e ch jest moralnym obowiązkiem c zło w i e k a "23. Niezbędność optymizmu, którą Miciński nazwał potrzebą „uśmiechania się każdym słowem”, poeta deklaruje jeszcze przed „wejściem” w sam środek wydarzeń na balu. Bez względu na to, jaki będzie finał zabawy, wierzy, że spełnią się marzenia kochanka i kochanki o szczęściu rodzinnym. Spełnienie pragnień zależne jest od istoty ich uczuć i od spraw świata.

21 B. Miciński, Pochylmy się nad wierszami Gatczyńskiego, [w:] tenże, Pisma. Eseje. Artykuty. Listy, Kraków 1970, s. 300.

22 Tamże, s. 301

23 Tamże. 


\author{
Na zielone wianki \\ przyjdzie jeszcze czas: \\ dom kochanka, kochanki: \\ obłok, niebo, las. \\ Napełnimy szklanki \\ w przedwieczorny czas \\ i spokojne usta w wino \\ pochyli chwila, \\ świat na chwilę zasuszy nas \\ jak Biblia motyla.
}

Marzący o szczęściu domowego ogniska kierują wzrok ku niebu, ku przyrodzie, rodzących poczucie bezmiaru świata, nieskończoności, która ich ludzki byt przekracza. Stąd pojawia się pragnienie, żeby chwile szczęścia trwały, i to pragnienie istnienia budzi wiarę, że kiedy ich życie przekroczy granicę świata naturalnego, granicę ziemskiego czasu - wtedy dla nich otworzy się nieskończoność czasu, o jakim mówi Biblia. I to oznajmienie nadziei - „świat na chwilę zasuszy nas/ jak Biblia motyla" - jest z ducha metafizyczne, ponieważ sięga do najgłębszych źródeł istnienia, odsłania to, co zakryte ${ }^{24}$. „Świat na chwilę" - to bezkres czasu, który odsłania to, co transcendentne, nieśmiertelne. W porównaniu: „Świat zasuszy nas/ jak Biblia motyla” - zamknięte zostało metafizyczne poczucie kruchości istnienia, a zarazem jego nieskończoności domknięte w symbolu duszy (motyla) złączonej z Bogiem.

Za wszystkimi przymiotami artystycznej maestrii Gałczyńskiego twierdził Miciński - kryje się tajemnica jego wrażliwości. W tym słowie „maestria” umieścić by też można pomysłowość, intelektualizm, żywość wyobraźni, upodobanie do dziwności, a także niezwykłych porównań. Umie-

24 Na Ogólnopolskiej Konferencji Naukowej „K. I. Gałczyński-miejsca niedoczytane. Obraz świata - biografia - język”, która odbyła się w dniach 7-8 VI 2019 r. w Leśniczówce Pranie, prof. Dariusz Kulesza (UwB) i dr hab. Jerzy S. Sikora, prof. UKSW - w dyskusji zgłosili uwagi, że liryka Gałczyńskiego z trudem mieści się w paradygmacie poezji metafizycznej. Z kolei dr Krzysztof Korotkich (UwB) w dyspucie ze mną przekonywał, że w rozważanej sprawie rozstrzygnąć przyjdzie kwestię, jak to, co się nie mieś c i w modelu metafizycznym - na model ten oddziałuje? Za wskazanie tych ciekawych problemów recepcji i interpretacji - dzisiaj widzę, że rodzących potrzebę przyszłych badań - wszystkim dyskutantom bardzo dziękuję. 
ścić by trzeba także kunszt ,ironicznego konceptyzmu”25, często przez poetę wyzyskiwanego, jak choćby w strofie inspirowanej filozoficzną koncepcją wszechświata.

Po skośnych górach z papierosem

i po księżycach, od których mdli, wchodzę w świątynię bogini Li, która stworzyła świat splunięciem.

Po świętej rzece Irawadi pływają lampy w Dzień Zaduszków, a Li tymczasem leży w łóżku, która stworzyła świat splunięciem. „Sedens in coelis ridet" - Dawid mówi tak w psalmie - sprawdzić można. Jakże zazdroszczę ci, bezbożna Li, co stworzyłaś świat splunięciem!

Cytat „Sedens in coelis ridet” - „Śmieje się Ten, który mieszka w niebie" - pochodzi z Dawidowego Psalmu II, 4. Odnosi się do Boga śmiejącego się z ludzkich uzurpacji; ten zamaskowany motyw dokumentuje umiejętność konstruowania przez Gałczyńskiego form groteskowych, kojarzenia sprzecznych porządków motywacyjnych, zdolność zaskakiwania niespodziewanym dowcipem - poświadcza walory od zawsze cenione w rozwoju poezji metafizycznej.

Adam Kulawik ów „niebiański śmiech” traktuje jako wyraz pogardy wobec tych, którym na naszym padole do śmiechu nie jest ${ }^{26}$. Rozpatrywana przez niego ,poetyka puzzli”, kompozycyjnego chaosu, niejasnych konstrukcji myślowych w poemacie, służy przedstawieniu ,szamotaniny, buntu, udręki, osaczenia i beznadziei”, a na koniec rezygnacji człowieka pobitego,

25 Pod pojęciem, ,ironicznego konceptyzmu” rozumiem inspirację ironiczną moralistyką Norwida oraz dziedzictwem anglosaskiego modernizmu. Zob. A. Van Nieukerken, Ironiczny konceptyzm. Nowoczesna polska poezja metafizyczna $w$ kontekście anglosaskiego modernizmu, Kraków 1998, s. 10-64.

26 A. Kulawik, Poezja to jest złoty szerszeń, s. 57. 
sponiewieranego przez $\operatorname{los}^{27}$. Odsłanianie głębszych przyczyn ,absurdalności i koszmaru świata", tragiczności klęski bohatera, tego, co wstrząsające, tajemnicze i niepojęte w sytuacjach życiowych oraz międzyludzkich i ponadludzkich zdarzeniach, należy do zestawu problemów poezji metafizycznej, odsłaniającej sens życia ludzi - wedle katastroficznych interpretacji poematu - wiedzionych na zgubę.

Mimo wszystko, moje wątpliwości budzi przekonanie o tragiczności klęski bohatera Balu u Salomona, albowiem klęska nie do końca mieści się w personalistycznym światopoglądzie autora Serwus, Madonna i innych wierszy poświęconym nadziei, w którą wpisana została metafizyczność. Z personalizmu chrześcijańskiego Gałczyński wyprowadza cały swój system przekonań ideowych i artystycznych, w którym człowiek jest osobą wolną i moralną, aczkolwiek w swej istocie tragiczną i paradoksalną. W omawianym poemacie potęga wolnego ducha nagle poetę przeraża, gdy widzi, że wraz z każdym zamierzeniem, każdym czynem nie opuszcza go dziwne poczucie tego, co nazwalibyśmy „złem”, co wiąże się ze świadomością krzywdy wyrządzonej osobom bliskim. Czym jest owo zło, owa krzywda, skoro niesie ze sobą poczucie winy - to już sprawa przesiąkniętej metafizyką wykładni etycznej.

\section{V}

Nacisk Kazimierza Wyki na tezę, że poezja Gałczyńskiego jest odosobnionym, „przedziwnym zjawiskiem czystej poetyckości” w liryce Dwudziestolecia, każe zwrócić uwagę na pewien jej odpowiednik pośród „przedziwnych zjawisk artystycznych" w poezji europejskiej tamtego czasu. Kierunek właściwych odwołań komparatystycznych wskazuje poezja Laforgue'a - silnie oddziałująca na kształt artystyczny wczesnych utworów Thomasa Stearnsa Eliota. A przecież nie kto inny, jak właśnie Gałczyński, studiując na Uniwersytecie Warszawskim u profesora Andrzeja Tretiaka anglistykę, miał szansę zainteresowania się twórczością autora Ziemi jałowej oraz angielskimi poetami metafizycznymi XVII wieku, którzy inspirowali poezję Eliota do wejścia w przestrzeń wyobraźni religijnej.

Na obwolucie Utworów poetyckich Gałczyński informował, że równocześnie z anglistyką studiował filologię klasyczną u profesora Tadeusza Zielińskie-

27 Tamże, s. 64. 
go. Przypomnijmy - światowej sławy uczonego, najwybitniejszego polskiego humanisty tamtych czasów, nominowanego do literackiej nagrody Nobla, i przed Eliotem - proponującego nowe spojrzenie na kwestię tradycji oraz jej znaczenie dla współczesności zarówno w wymiarze literackim, jak i kulturowym $^{28}$. Bal u Salomona mógłby zyskać nowy format hermeneutyczny, gdybyśmy dostrzegli w nim urzeczywistnienie Eliotowskiej tezy o niezbędności tradycji kultury w ugruntowaniu cywilizacji współczesnej - którą od kryzysu kulturowego uratować mogą wartości transcendentne. Katastroficzne poematy londyńskiego poety są ostrzeżeniem dla zmaterializowanej i pustej cywilizacji współczesnej, która sprzeniewierzyła się swoim wartościom metafizycznym, i stała się zaprzeczeniem własnych ideałów ${ }^{29}$. Skutki historyczne oraz duchowe I wojny światowej, następstwa wielkiego kryzysu gospodarczego, narastanie w Europie ruchów faszystowskich sprawiły, że ,wydrążeni ludzie”, zamieszkujący „ziemię jałową”, nie potrafili odnaleźć sensu istnienia. Na planie wyobraźni eschatologicznej i metafizycznej wnioski Eliota i Gałczyńskiego były w dużej mierze zbieżne. W twórczości obu poetów wizja grożącej światu zagłady miała zasadnicze znaczenie dla uformowania personalistycznego kształtu metafizycznej poezji lat 30. i 40. ubiegłego stulecia.

W Utworach poetyckich Gałczyński objawił się jako pisarz, który nie boi się wchodzić na tereny nawet najbardziej rozbieżnych idei, na tereny uważane za niegodne poezji, a zaiste są to tereny bardzo bliskie metafizycznej poezji jej klasyka - Thomasa Stearnsa Eliota. Wielka to szkoda, że Eliot, kierując zasłużone pochwały pod adresem metafizycznych poetów śródziemnomorskich (Dante) i anglosaskich, nie znał poezji Sępa-Szarzyńskiego i Cypriana Kamila Norwida - bezsprzecznie dwóch największych zachodnioeuropejskich poetów metafizycznych ${ }^{30}$. Wówczas jego wiedza o źródłach europejskiej kultury literackiej byłaby pełniejsza. A z tych źródeł czerpał Gałczyński. Aż się prosi, choć jest to przypadek szczególny, żeby natchnionej frazy „życie wiekuiste i śmierć płonna” z Serwus, Madonna, szukać

28 Zob. L. Winniczuk, Trwate i aktualne wartości puścizny naukowej Tadeusza Zielińskiego, [w:] T. Zieliński, Legenda o złotym runie, wybór A. Biernackiego, wstęp J. Krzyżanowskiego, posł. L. Winniczuk, Kraków 1972, s. 361-371.

29 M. Heydel, Obecność T. S. Eliota w literaturze polskiej, Wrocław 2002, s. 44-45.

30 Zob. A. Van Nieukerken, Ironiczny konceptyzm, dz. cyt., s. 35-64. 
u źródeł myśli Sępa-Szarzyńskiego, a „potężną dobroć” w Pieśni cherubińskiej - skojarzyć z etyką Norwida.

Śladów zainteresowania twórczością autora Ziemi jałowej, czy to w postaci swoistych paraleli myślowych, czy podobnego rozpoznania psychicznej, duchowej i religijnej sytuacji tamtego czasu, bądź pewnej „równoległości” katastroficznych wizji świata, doszukiwać się można nie tylko w Balu Salomona. Przenikliwe uwagi krytyczne Wyki, które dotyczyły oddziaływania tradycji dekadenckiej poezji symbolistów francuskich, trafne spostrzeżenia Gombrowicza na temat harmonizowania elementów pochodzących z różnych porządków estetycznych, zasadne twierdzenia Kulawika o egzystencjalnym koszmarze, uzupełnione poczynionymi tutaj obserwacjami na temat elementów codzienności łączonych z metafizycznością oraz wyzyskiwania przez Gałczyńskiego dygresji kulturowych i aluzji literackich - muszą się kojarzyć z inspiracjami twórczymi, na jakich opierała się poezja Eliota. Porównania tendencji ideowych, zbieżności, różnic i analogii artystycznych, wpływów angielskich poetów metafizycznych XVII wieku, odciskających swoje ślady w języku i poetyce twórczości autora Ziemi jałowej i Wydrążonych ludzi, oraz przez jego poezję mogące promieniować na wielogłosową organizację poematów Gałczyńskiego, stanowią wyzwanie dla komparatystów, chcących gruntowniej zbadać dalsze zbieżności rysów liryki obu pisarzy ${ }^{31}$.

\section{VI}

W liryce Gałczyńskiego uprzywilejowane miejsce zajmuje Eliotowski wzorzec „prześwitywania”. Wówczas znane symbole, motywy i postaci przeszłości oraz realia ich epoki pojawiają się w tle danej sytuacji lirycznej, i przydają głębi znaczeniowej motywom pierwszego planu, nierzadko same ulegając przy tym reinterpretacji, a niekiedy rywalizują nawet o miejsce naczelne w percepcji, konkretyzacji oraz interpretacji całej wypowiedzi poetyckiej ${ }^{32}$. Ze wspomnianym ,prześwitywaniem” możemy się spotkać, kiedy przez wier-

31 Gałczyński mógł poznać twórczość Eliota w trakcie studiów anglistycznych, następnie własnych lektur utworów poety, być może podczas pobytu w Berlinie, ponadto z esejów Wacława Borowego, czy przekładów wierszy londyńczyka pióra Józefa Czechowicza. Zob. M. Heydel, Obecność T. S. Eliota w literaturze polskiej, dz. cyt., s. 18-47.

32 A. Lam, Aluzje literackie, szyfry i cytaty z poezji Gatczyńskiego, [w:] Poznać to, co mówimy. Prace filologiczne i wspomnienia, Warszawa 2009, s. 82-86. 
sze przewijają się poeci: Horacy, Kochanowski, Goethe, Mickiewicz, Norwid, którzy na różne sposoby, w odmiennych tonacjach - konfidencjonalnych, wzniosłych, parodystycznych - bywają w wierszach obecni, obecnością swoich dzieł, obrazów, symboli.

Wiersz Horacjusza wydania weneckie przywodzi na myśl głoszoną w odach, satyrach i listach mądrość życiową rzymskiego poety. Roztacza szczególną aurę asocjacyjno-emocjonalną, wzbudza intelektualne refleksje odbiorców, którym Gałczyński wskazuje niebezpieczeństwo grożące cywilizacji łacińskiej, ale przede wszystkim stojącej na jej straży Polsce:

\author{
Horacjusza wydania weneckie... \\ i trochę czarnej kawy po obiedzie, \\ lepszego tytoniu szczypta, bzy tureckie \\ i dobry, duży księżyc, który wzejdzie:
}

Oto wszystko, co mi może zniszczyć polska "rewolucja”, ciemna gawiedź w rękach smutnych psychopatów.

Moment osadzenia dzieł Horacego w życiu bohatera jest cezurą, która ustanawia egzystencjalną relację między nim i światem wartości wyrażonych w relacjach metafizycznych jako faktach wpisanych w jego istnienie. Zagrożenie metafizycznych wartości świata przeżywanego udobitnia katastroficzną przestrogę, którą Gałczyński wcześniej przedstawiał w szeregu wierszy antysowieckich ${ }^{33}$. Przed niszczycielskimi skutkami „polskiej rewolucji”, wywołanej przez „dzikie biesy” na ziemiach polskich, przestrzegał Stefan Żeromski w głośnym reportażu. Na probostwie w Wyszkowie. Przed następstwami dziejowymi rewolucji ostrzegał także najwybitniejszy (obok Feliksa Konecznego) polski historiozof tamtej epoki - Marian Zdziechowski, rektor USB, z którym Gałczyński „mógł się zetknąć” podczas pobytu w Wilnie. Zapewne nie w trakcie spotkania autorskiego na uniwersytecie, gdzie przypuszczalnie recytował także Bal u Salomona, lecz, co bardziej prawdopodobne, na którejś ze „Śród Literackich” przy Ostrobramskiej 9, lub po prostu w wileńskim „Słowie”, na którego łamach autor Wpływów rosyjskich na duszę polska kontestował nihi-

33 Zob. E. Pogonowska, Dzikie biesy. Wizja Rosji Sowieckiej w antybolszewickiej poezji polskiej lat 1917-1932, Lublin 2002, s. 224-225, 230-237. 
lizm komunizmu sowieckiego. W Balu u Salomona zawarta była przestroga, stanowiąca podstawę idei katastrofizmu Zdziechowskiego, że następstwem destrukcyjnego projektu „śmierci Boga” będzie proces dehumanizacji człowieka, a wraz z nim ziści się widmo zagłady Europy. Horacjusza wydaniami weneckimi - po raz pierwszy pomieszczonymi w Utworach poetyckich - Gałczyński potwierdzał swój współudział w nurcie piśmiennictwa ostrzegającego przed tragicznymi skutkami „polskiej rewolucji” ${ }^{34}$.

Z kolei nieco wcześniej, w ogłoszonym na łamach „Śród Literackich” (1936 nr 4) wierszu Farlandia, dowodził, że komunizm to niszczycielska siła skierowana przeciw pomyślności zwykłych ludzi.

Myśmy mieli się spotkać na moście,
by pomówić o naszej miłości,
pod tym klonem, koło budki z papierosami;

ale, jakem przewidywał: oczywiście

most w powietrze wysadzili komuniści35, no to gdzie się teraz spotkamy?

Wszędzie duszno i ciasno - lecz znam ja

34 Zob. J. S. Ossowski, Szarlatanów nikt nie kocha. Studia i szkice o Gatczyńskim, Kraków 2006, s. 237-238.

35 Kanoniczną wersję tego wiersza, wyraźnie wskazującą, że sprawcami miejskiego terroru byli komuniści, po raz pierwszy przedstawiłem w roku 1994 na konferencji naukowej, a następnie udostępniłem w zbiorze studiów o Gałczyńskim, Szarlatanów nikt nie kocha, Kraków 2006, s. 231. Edytorzy utworów Gałczyńskiego z tym, by w Farlandii, tak jak w pierwodruku, „pojawili się komuniści” - zwlekali do roku 2014. Zob. K. I. Gałczyński, Szarlatanów nikt nie kocha. Wiersze zebrane, t. I, Warszawa 2014, s. 328. To ostatnie wydanie nie spełnia kryteriów pełnego wydania krytycznego, ponieważ znalazło się w nim wiele błędów redakcyjnych i edytorskich, powtórzonych za wydaniem Dzieł z roku 1979; ponadto nie przywrócono w nim postaci pierwodruków wierszy przedwojennych i autorskich profili wierszy powojennych - a w obu wypadkach były to wersje tekstów ocenzurowane - zniekształcające twórczą wolę Gałczyńskiego. Ponadto w tej edycji nie ma utworów poetyckich, które nadal pozostają czy to $\mathrm{w}$ stanie rękopiśmiennym, czy w formie pierwodruków prasowych. Żadnego z wierszy opublikowanych nie skonfrontowano z rękopisami, maszynopisami albo pierwodrukami czasopiśmienniczymi. Najpopularniejszy poeta polski minionego stulecia nie ma do dziś rzetelnego, pełnego krytycznego wydania swoich dzieł, sumiennej bibliografii podmiotowo-przedmiotowej, profesjonalnej kroniki życia i twórczości, uczciwej biografii, kompetentnego opracowania recepcji, solidnego wydania zbioru studiów i szkiców o swojej twórczości, napisanych przez najwybitniejszych krytyków i literaturoznawców. 
pewien kraj pod nazwą Farlandia, tam jest niebo śpiewające i palmy.

No, no, nie płacz, nie troskaj się, nie martw, że tego mostu już nie ma my się jutro w Farlandii spotkajmy.

Mężczyzna, starając się pocieszyć strapioną i płaczącą kobietę, wybiega marzeniami w przyszłość, dostrzega metafizyczny trop, który prowadzi ku arkadii, gdzie pragnienie szczęścia może się spełnić. W ten sposób idylla demistyfikuje komunistów, którzy, opierając się na sile ekspansywnej ideologii marksistowskiej oraz „,zerwonym terrorze”, aby szybciej doprowadzić ludzkość do rajskiej krainy kolektywnej szczęśliwości na ziemi, wysadzają most. Farlandia mówi też o tym, że nadziei nie wolno tracić, że daje ona moc ludzkiemu istnieniu, w którym każdy może spodziewać się szczęścia, o ile postępuje szlachetnie.

Wyraz bardziej ostentacyjnego, przekornego nastawienia antysowieckiego dawała - dedykowana hrabiemu Michałowi Tyszkiewiczowi - antykomunistyczna satyra Pardon z ZSRR. Jej bohater - apologeta „burżuazyjnego" stylu życia - drwiąc z Marksa i bolszewickiej Rosji, czuje się wolny. W obliczu śmiertelnego zagrożenia sowieckiego chce być wolny nieskończenie. Toteż przekornie oświadcza: „Że Untergang des Abendlandes?/ Gwiżdżę rastaquoère!”. I tym stwierdzeniem nadaje uskrzydlającej, metafizycznej mocy swojemu ,ja"36. W jego ,ja" wzbudza się poczucie tożsamości, która opiera się na władzy wolnego ducha polskiego nad ZSRR, ducha sarmackiego, jaki napawa się rozkoszą przekory.

\section{VII}

Metafizyczna poezja Gałczyńskiego obejmuje najtrudniejsze do adekwatnego przedstawienia $\mathrm{w}$ formie mowy poetyckiej misteria istnienia - najbardziej wewnętrzne ze wszystkich doświadczeń - jakie mogły się stać udziałem egzystencji człowieka. Dla tajemnic istnienia, które same w sobie pozostają w sferze niewyrażalnego, Gałczyński znajduje stosowny, artystycznie trafny język ewokujący piękno, radość bycia-ku-miłości (Polowanie z sokołami)

36 Zob. B. Skarga, Kwintet metafizyczny, Kraków 2005, s. 192-193. 
i trwogę bycia-ku-śmierci (Noctes Aninenses). Owe doświadczenia, najczęściej dające się określić mianem niepokoju egzystencjalnego, bez wątpienia zasługują na miano metafizycznych, nie są bowiem codziennymi doświadczeniami bytu i bycia, zwłaszcza kiedy dotyczą istnienia człowieka przygodnie osadzonego między niebem, ziemią i ludźmi, a więc człowieka rzuconego w świat i historię.

Doświadczenie przygodności istnienia leży u podstaw sytuacji, którą tak sugestywnie stawia nam przed oczami niezwykły wiersz Serwus, Madonna ${ }^{37}$. Życie człowieka od samego początku zostało skorelowane ze śmiercią. Świadomość tej korelacji czyni niezbędnym światopoglądowe określenie się poety. Niepokój egzystencjalny, jaki go ogarnia, jest wypadkową zdania sobie sprawy z kruchości życia, jak gdyby zawieszonego w „czymś”, co jest od niego „inne”, metafizyczne, jak towarzysząca mu od dzieciństwa „obecność” Madonny. Matka Boża poprzez swoją nad nim opiekę w pewien sposób „uzależnia” swymi wstawiennictwami jego własne istnienie. „Uzależnia” istnienie, czyli objawia swą moc transcendentną.

Byli inni przede mną. Przyjdą inni po mnie,

Albowiem życie wiekuiste, a śmierć płonna.

Wszystko jak sen wariata śniony nieprzytomnie -

Serwus, Madonna.

To Ty jesteś, przybrana w złociste kaczeńce,

Kwiaty mego dzieciństwa, Ty, brama obronna -

Że rosa brud obmyje z rąk, splatam Ci wieńce -

Serwus, Madonna.

37 Cytuję za: K. I. Gałczyński, Serwus, Madonna, [w:] Utwory poetyckie, Warszawa 1937, s. 138. Po wojnie „smutni psychopaci” zmienili treść tej lirycznej wypowiedzi religijnej, zastępując kluczową frazę słowami: ,a ty jesteś matka moja, kochanka i muza” - co cały utwór czyni niedorzecznym, bo niby czemu owa „ona" - interpretatorzy snują domysły, że to Natalia, ,poezja” - ma być akurat „,cicha i wonna”, a nie „,cicha i płonna”, albo „cicha i skłonna”? Puentą nocy skrapianych alkoholem mogłaby być raczej „rosa zaranna”, albo „zorza poranna"? Jeśli poeta stwierdza wyżej, że nie dla niego ruń wonna, to dlaczego kwiaty jego dzieciństwa - złociste kaczeńce - miałby skojarzyć mu się teraz z ciszą i wonnością? Kniecie błotne nie pachną! Z doświadczenia życiowego wiem, że matka (mama) może być „cicha”, kochanka „wonna”, ale u Gałczyńskiego muza „cicha”? 
Nie gardź wiankiem poety, łotra i łobuza -

Znają mnie redaktorzy, zna policja konna,

a tyś jest Arka moja, Victoria i Muza -

Serwus, Madonna.

Doświadczenie przygodności życia w wyznaniu lirycznym Serwus, Madonna przynagla poetę do przedstawienia swoich zapatrywań na sens istnienia, który zawiera się w słowach, jakie dotyczą „życia wiekuistego” oraz „płonnej śmierci”, a także słowach dziękczynienia i zawierzenia Madonnie. Stąd, zgodnie z logiką wiary, po stwierdzeniu: „Ty, brama obronna” następują słowa dziękczynienia: „Że rosa brud obmyje z rąk, splatam Ci wieńce” definiujące rzeczywistość duchową, w jakiej zanurzony jest bohater wiersza ${ }^{38}$. Wiersz, sięgając tajemnicy istnienia człowieka, jest lirykiem metafizyczno-religijnym ${ }^{39}$. W ostatniej strofie zawiera się emocjonalno-refleksyjna kumulacja jego semantyki, zaś najgłębszy sens metafizyczny utworu potwierdza konstatacja: „A Tyś jest Arka moja, Victoria i Muza/ Serwus, Madonna”.

W refleksji nad sobą, nad własnymi doświadczeniami życiowymi oraz swoim miejscem w świecie Gałczyński tworzy niepowtarzalny projekt własnego bycia, który nie zamyka się „tu i teraz”, i nie orientuje się na nieuniknioną śmierć, ponieważ zdając się na orędownictwo Matki Stwórcy - zawsze

38 Poprawki powojenne sprowadzają wiersz do poziomu dosłowności; po prostu do monologu poety opisującego swoje życie; nie skupiają się na metafizycznych obrazach treści tego życia, cofają cały utwór w kierunku znaczeń powierzchownych, w stronę młodopolskiego symbolizmu, a więc ku poetyce nie tylko całkowicie Gałczyńskiemu obcej, ale wręcz przez niego wyśmiewanej.

39 Obiektywną i dogłębnie przemyślaną hermeneutykę tego utworu przedstawił A. Kulawik, „Serwus, madonna” Konstantego Ildefonsa Gałczyńskiego”, [w:] Literatura polska w szkole średniej, praca zbior. pod red. S. Grzeszczuka, wyd. IV, Warszawa 1990, s. 386-397; t e n ż e, Serwus, Madonna, czyli Przykrość, jaka zrobitem Natalii, [w:] Poezja to jest złoty szerszeń, Kraków 2014, s. 33-43. W ostatnim eseju autor dowodzi, że adresatką wiersza jest muza poezji, Euterpe. Interesującą uwagę o tym wierszu, o miejscu tego utworu w porządku aksjologicznym poezji minionego stulecia, 9 kwietnia 1950 roku w Dzienniku zapisał Jan Lechoń: „Grydzewski przesadza, gdy mi pisze, że po „skamandrytach” nie odróżnia już poetów. Ja odróżniam, ale odróżniam też Miłosza od poetów, którzy coś naprawdę własnego stworzyli. [...] Nie chcę się kłócić, ale myślę właśnie, że to jest „nikt”. Nie widzę nic Miłosza w jakiejś antologii za sto lat. A na przykład Serwus Madonna Gałczyńskiego zawsze da się czytać". J. Lechoń, Dziennik, T. I, Londyn 1967, s. 210. Dzisiaj nie ma antologii bez tekstów Miłosza, ale są antologie bez wiersza Serwus, Madonna. 
obecnej w jego życiu - staje po stronie nadziei. Nadzieja jako metafizyczna osnowa istnienia człowieka, zawsze powraca, rozprasza niepokój, toteż wita się ją radosnymi słowy: „Serwus, Madonna”. Nadzieja, że Madonna czuwa, daje poecie moc bycia, i pozwala mu trwać w przekonaniu, że ma jeszcze czas, że czas może przezwyciężyć, zyskując wszystko, co dla niego istotne ${ }^{40}$.

\section{VIII}

W warstwie treściowej wierszy religijnych Gałczyńskiego uwagę zwraca współistnienie - na szczególnych prawach - tematyki świeckiej i religijnej, przeto wzajemne przenikanie się obu tych obszarów, na których odsłania się głębszy sens życia (Serwus Madonna, Modlitwa do Anioła a Stróża). W tych wierszach poeta wyzyskuje obszerny katalog jakości metafizycznych, takich jak: tragiczność, upadłość, wzniosłość, tajemniczość, grzeszność, świętość, ekstatyczność, groza, uspokojenie, nadzieja, które - nieraz z pomocą humoru, drwiny czy ironii - odsłaniają głęboko ukryty sens życia człowieka, ujawniają prawdę jego bycia w obu światach, tym realnym, i tym metafizycznym. Tak rzecz się przedstawia w Modlitwie polskiego poety, utworze quasi-religijnym, dla którego zaprezentowania wystarczy kilka wybranych zwrotek.

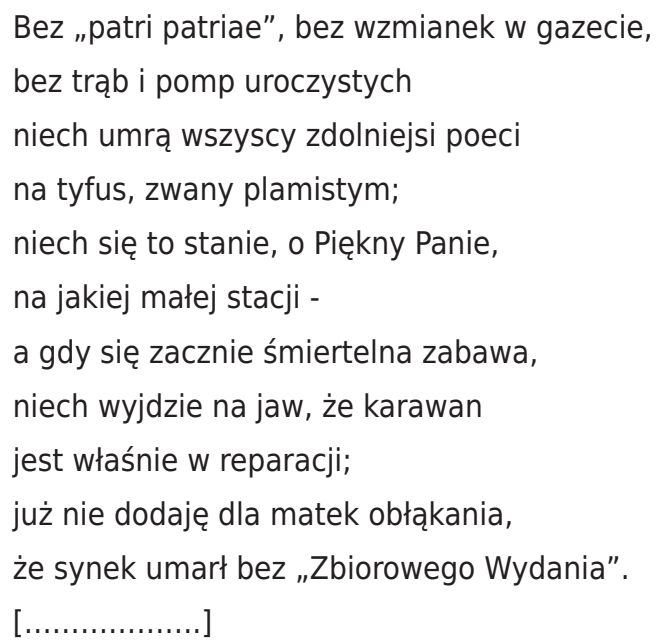

Następuje antyfona:

40 B. Skarga, Źródła metafizyczności, [w:] Kwintet metafizyczny, dz. cyt., s. 195-196. 
Tak modlę się, błędny anioł,

gdy niczym Pascal stoję nad otchłanią,

zapatrzony z mostu w Wilenkę.

Już Heraklit powiedział z Iwowska PANTA RHEI,

PANTA RHEl, ale nic si nie dziei,

chyba w niebie, gdzie gwiazdy taką śpiewały piosenkę:

Już się zaczyna, już się zaczyna,

zaraz przyjedzie na most dziewczyna

z Warszawy w lazurowej karecie,

smagła dziewczyna o rzewnych rzęsach,

co kocha Matkę Boską i Dickensa

i sercem świeci poecie.

W tej groteskowo-ironicznej wypowiedzi satyrycznej - po wielu niespodziankach sytuacyjnych, które przepełnia czarny humor, po refleksyjnym nawiązaniu do rozterek Pascala - Antyfona wyraża pewien, od początku nie opuszczający poety, niepokój przybliżania się do tajemnic istnienia, o których się wie, że są, że czekają, przyzywają, chcą być odsłonięte i nazwane. Wówczas bycie poety przedstawione w wierszu zdaje się byciem radosnym. Moc nieba nadaje ostateczny sens jego egzystencji, co poeta przekłada na nadzieję spotkania z ukochaną. Symbolika tego spotkania odsyła nie tylko do uczuć dwojga ludzi, ale także czegoś, co zawiera się w przesłaniu piosenki śpiewanej przez gwiazdy, co nobilituje „dziewczynę”, która - mając w sercu miłość do Matki Boskiej i Dickensa - może sercem świecić poecie. Odkrywanie, „wydarzenie się prawdy" w Modlitwie polskiego poety najpierw zmierza do ujawnienia problemów egzystencji pisarza, które okazują się być rozterkami istnienia, a w końcu doprowadza do odsłonięcia przeświadczeń metafizycznych, których konsekwencją staje się prawda o pięknie miłości.

Liryki zgromadzone w Utworach poetyckich potwierdzają, że Gałczyński miał zdolność nadzwyczajnego odkrywania bogactwa duchowych doświadczeń, tajemnic istnienia, zdolność odsłaniania i ujawniania czegoś metafizycznego, co w rzeczywistości najgłębsze i najbardziej istotne. W ten sposób pozwalał prawdzie, dobru i pięknu być - pozwolę sobie użyć tu Heideggerowskiego terminu - istoczącymi się tajemnicami istnienia, którymi są naprawdę, 
jak w wierszach adresowanych do żony, a tych w omawianym tomie poetyckim pisarz zamieścił najwięcej. Bez trudu można w nich wyczuć intencję ukazania autentycznej miłości pomiędzy małżonkami oraz odkrycia - w dużej mierze określonej przez ideały chrześcijańskie - godności małżeństwa i związanej z nią odpowiedzialności. Z pewnością metafizyczne klucze do światów wyobraźni poety ewokowanych w jego liryce miłosnej okażą się nadzwyczaj pomocne w otwarciu również i na tę problematykę.

\section{IX}

Najważniejszymi aspektami metafizycznej twórczości lirycznej Gałczyńskiego, widzianymi na tle całości jego dzieła, są wizje upadku pozbawionej transcendentnego wymiaru cywilizacji zachodniej i podejmowane $\mathrm{z}$ eschatologicznej perspektywy pytanie o istotę człowieka i jego powołanie. Sens tego powołania odsłania się przez decyzje bohaterów wierszy mające dla nich doniosłe skutki duchowe oraz moralne. Metafizyczna perspektywa nadaje ich egzystencji pewien ład aksjologiczny, który stanowi mocną przeciwwagę dla wszystkiego, co o twórczości Gałczyńskiego pisano w latach powojennych. Dostrzeganie w autorze Notatek z nieudanych rekolekcji paryskich poety metafizycznego, który poprzez wysiłki moralne i poetyckie wznosi się od świadomości katastroficznej do świadomości transcendentnej prawdy o człowieku - nie było możliwe w czasach PRL-u. Proroctwa Gałczyńskiego na temat upadku cywilizacji zachodniej wyśmiewano. Tymczasem w tych katastroficznych proroctwach, zapisanych w Balu u Salomona, Pieśni o szalonej ulicy, Noctes Aninenses, Notatkach z nieudanych rekolekcji paryskich, był on poetą nowatorem, twórcą dykcji lirycznej odmiennej od wszystkiego, co było obecne w polskiej poezji I połowy XX wieku. Potrafił bowiem rzeczywistość emocjonalną i refleksyjną wraz z własnymi zasobami wyobraźni - przedstawiać w sposób zobiektywizowany przez ciągi obrazów, symboli oraz formy monologów wewnętrznych person lirycznych. Taka nowoczesna poetyka - kojarzona przede wszystkim z twórczością Eliota - była najważniejszą propozycją ideowo-artystyczną dla polskiej poezji nie tylko w latach 30. ubiegłego wieku.

W tym miejscu dotykamy sedna trudności recepcji, konkretyzacji i interpretacji twórczości Gałczyńskiego, ponieważ stanowi ją splot nowatorstwa z głębokim zakorzenieniem w tradycji, z jakiej obficie poeta korzystał. Na nowatorstwo Gałczyńskiego, choć nie używając tego pojęcia, pierwsi zwrócili uwagę 
recenzenci Utworów poetyckich (1937), Witold Gombrowicz, Kazimierz Wyka, ale także Stefan Lichański, który Bal u Salomona uznał za najlepszy z zawartych w zbiorze tekstów, oscylujący na granicy możliwości poezji tradycyjnej, zdolny „ujarzmić uwagę czytelnika i zahipnotyzować go magią poetyckiego uro$\mathrm{ku}^{\prime 11}$. Za odkrywcze i ważne krytyk uznał to, co autor manifestu Do przyjaciót $z$,Prosto z mostu” mówił o powadze sztuki, o jej nadprzyrodzonych inspiracjach, o potrzebie świadomości moralnej artysty, zgadzając się tu z Norwidem - nauczycielem jego pokolenia. Niedostatki poematu, ale też innych utworów lirycznych, dostrzegł Lichański w braku określonej „ideologii artystycznej”, wynikającej ze zbytniego - podobnego wielkim romantykom - przywiązywania wagi do uczuć, do irracjonalnych intuicji twórczych, w czym Gałczyński odstępował od Norwida, wyżej ceniącego estetyczne konkrety religijne.

W ówczesnej diagnozie braku ,ideologii artystycznej” zawierały się, niemożliwe wówczas do hermeneutycznego uprzytomnienia, artystyczno-ideowe dominanty poezji nowoczesnej, kreacyjnej, wyprzedzającej swoją epokę. Dzięki nowatorskiej technice poetyckiej, wielogłosowości, obrazom niezwykle skondensowanym, lapidarnym formom słownym, likwidacji przedziałów między rzeczywistością i fikcją, dzięki poetyce groteski i ironii, powstał poemat metafizyczny nie mający swojego odpowiednika w nurcie poezji katastroficznej Dwudziestolecia. Dzisiaj wiemy, że Bal u Salomona stanowi sumę genialnego talentu poetyckiego i erudycji Gałczyńskiego, jego wiedzy o świecie współczesnym oraz kulturze śródziemnomorskiej i chrześcijańskiej, z których perspektywy historiozoficznej widać, jak cywilizacja XX wieku zmierzała ku nieuchronnej katastrofie ${ }^{42}$.

\section{$\mathbf{X}$}

Aluzje literackie, tradycyjna topika, szyfry i cytaty, paradoksy, groteskowe antytezy, satyryczne negacje dla Gałczyńskiego są sposobami docierania do prawdy o niewyrażalnym, docierania do sfery bytu i bycia ponad czasem

41 S. Lichański, Poezja Gałczyńskiego, „Pion” 1938, nr 4, s. 4.

42 Dzisiaj ostrzeżenia o nieuchronnej katastrofie kojarzymy z mądrością Rogera Scrutona, i czekamy na polskich poetów, którzy, inspirowani kasandrycznymi przepowiedniami filozofa, napiszą poematy historiozoficzne. Może wśród tych poetów któryś uzna, że warto też, idąc za Gabrielem Marcelem, zwrócić przy tym uwagę na „metafizykę nadziei”’? 
i historią. Wzajemne konfrontowanie języków - wysokiego, potocznego, historycznego, politycznego, publicystycznego, wypróbowywanie ich wydolności ewokacyjnej w różnych, niekiedy skrajnych sytuacjach lirycznych, zarówno dramatycznych, jak i prześmiewczych, angażowanie przy tym czytelnika groteskowym lub ironicznym wyzwoleniem wzruszenia i humoru - daje Gałczyńskiemu patent oryginalności w skali poezji XX wieku³ ${ }^{43}$ Jego kreacje infantylnej, ale i dramatycznej, fantastyki słownej czynią go odnowicielem języka artystycznego poezji o takim znaczeniu, jakie przypisuje się Gombrowiczowi w prozie ${ }^{44}$. Józef Czechowicz, wymieniając atrybuty liryki Gałczyńskiego: prostotę, groteskę, wysoką sztukę, uśmiech, mieszczaństwo, naiwność, alkohol i diabelstwo, nazwał tę lirykę - „wspaniałą strugą maestrii”"45. Jednakże do obcowania z podobnymi atrybutami wrażliwości artystycznej, czy modernistycznym podejściem do słowa, krytyka polskiej poezji nie była przygotowana, dostrzegając jedynie utwory przystępne, urzekające prostotą, niewymagające wielostopniowego wtajemniczenia, jakiego żąda obcowanie z liryką metafizyczną.

43 Osobowość i licentia poetica pisarza starałem się zgłębiać i opisać w rozprawach: Szarlatanów nikt nie kocha, Kraków 2006 oraz Sprawa Gałczyńskiego, Kielce 2011. Poza tymi rozprawami ogłosiłem studia i szkice: Arcyapostoł cywilizacji „Przekroju”, [w:] Kraków - Lwów. Książki - czasopisma - biblioteki XIX i XX wieku, T. IV, Kraków 1999; Potęga śmiechu, [w:] Świat w zabawie - „zabawa światem”, Olsztyn 2001; Notatki do „,Notatek z nieudanych rekolekcji paryskich”, „Annales Academiae Pedagogicae Cracoviensis. Studia Historicolitteraria" T. III, Kraków 2003; Gatczyński znany i nieznany, [w:] Konstanty Ildefons Gałczyński znany i nieznany, Katowice 2005; Postawa tragiczna $w$,,Notatkach z nieudanych rekolekcji paryskich”, [w:] Problemy tragedii i tragizmu, Białystok 2005; Gatczyński jako poeta tajemnic, [w:] Światto w dolinie. Prace ofiarowane profesor Halinie Krukowskiej, Białystok 2007; Gałczyńskiego tren na śmierć pięknej Wenecjanki, [w:] Profesor J. Żurawskiej. Studia ofiarowane przez kolegów i przyjaciót, Kraków-Warszawa-Napoli 2008; Echa antyczne w międzywojennej liryce Konstantego Ildefonsa Gatczyńskiego, [w:] Miscellanea literackie i teatralne (od Kochanowskiego do Mrożka), Łódź 2010; Uwagi o wileńskim poemacie katastroficznym „Ludowa zabawa”, [w:] Literatura - pamięć - kultura, Białystok 2010; Podejrzany egoizm awangardy, [w:] Między retoryka manifestów a nowoczesnościa, Kielce 2011; Poezja jest tylko dla tych, co maja czyste serca, [w:] K. I. Gałczyński, Szarlatanów nikt nie kocha. Wiersze zebrane, T. I, Warszawa 2014; Poezja jest tylko dla tych, co przez poezje pragna oczyścić się, [w:] K. I. Gałczyński, Portret muzy. Wiersze zebrane, T. II, Warszawa 2014 oraz „,Nagle wyszły Cyganki z zieleni”, [w:] Księga Jubileuszowa Prof. T. Wilkoń, Katowice 2019 [w druku].

44 A. Lam, Aluzje literackie, szyfry i cytaty w poezji Gałczyńskiego, [w:] Poznać to, co mówimy. Prace filologiczne i wspomnienia, Warszawa 2009, s. 85.

45 J. Czechowicz, Dwa aspekty, [w:] Wyobraźnia stwarzająca. Szkice literackie, wstęp, wybór i opracowanie T. Kłak, Lublin 1972, s. 184. 
Wielostopniowe wtajemniczenie hermeneutyczne jest nieodzowne wtedy, kiedy ważną rolę w liryce Gałczyńskiego odgrywają mity, które stanowią element nadający przedstawianemu światu harmonię i ład aksjologiczny oraz uniwersalizują przesłania wierszy i poematów. Przecież przywołanie w Balu u Salomona mitycznej przeszłości króla żydowskiego jest aktem przyswojenia tego wątku historiozofii dziejów, który dla współczesności ma istotne znaczenie. Wylewanie żalów badaczy na ten poemat, że jest trudny i niejasny, świadczy, że niezbyt dokładnie go czytali, a raczej konkretyzowali własną niechęć do tego utworu; co tylko podkreśla wagę, nieodzownego dla jego rozumienia, postulatu głębokiej, rzetelnej analizy i interpretacji. Niedorzecznością jest przecież traktowanie enigmatycznej postaci tytułowego Salomona jako demonicznego „zbiorowego Żyda” odpowiedzialnego za upadek cywilizacji europejskiej. Niedorzecznością jest twierdzenie, iż dopełnieniem antysemickiej wymowy poematu jest atakująca żydostwo filipika Do przyjaciót z „Prosto z mostu"46.

Badacze języka modernizmu, badacze groteski, ironii dowodzą wyższości nowoczesnej poezji Leśmiana, Przybosia czy Białoszewskiego w stawce o laury klasyków. Z satysfakcją znawcy poezji naszej epoki odwołują się do opinii krytyków związanych z „Wiadomościami Literackimi” (K. W. Zawodziński, M. Grydzewski, J. Tuwim) oraz późniejszych werdyktów A. Ważyka, Cz. Miłosza czy A. Sandauera, sprowadzających twórczość Gałczyńskiego do poziomu literackich bzdur. Świętymi poezji ubiegłowiecznej nadal pozostają skamandryci i awangardziści na czele z kanonizowanym Julianem Przybosiem, którego wiersze o śrubach i teorie rzutnika obrazów poetyckich od pewnego czasu badacze świeckiej epifanii zaczęli traktować jak utwory metafizyczne.

46 K. Nowosielski, ,Bal u Salomona”: salon, gulistan i Sodoma, „Topos” 2015, nr 4, s. 50. 


\section{Bibliografia}

Czechowicz J., Dwa aspekty, [w:] Wyobraźnia stwarzająca. Szkice literackie, wstęp, wybór i opracowanie T. Kłak, Lublin 1972, s. 180-184.

Gałczyński K. I., Szarlatanów nikt nie kocha. Wiersze zebrane, t. I., Warszawa 2014.

Gałczyński K. I., Utwory poetyckie, Warszawa 1937.

Gałczyński K. I., Wybór poezji, oprac. M. Wyka, wyd. VI zmien., Kraków 2003.

Gombrowicz W., Uwagi dyletanta [prwd. „Ateneum” 1938, nr 2], [w:] Proza (Fragmenty). Reportaże. Krytyka literacka 1933-1939. Dzieła, T. XII: Varia, red. J. Błoński, J. Jarzębski, Kraków 1995, s. 356-360.

Heydel M., Obecność T. S. Eliota w literaturze polskiej, Wrocław 2002.

Kulawik A., Bal i Arkadia - dwa kluczowe motywy liryki K. I. Gałczyńskiego, „Przegląd Humanistyczny" 1974, nr 6, s. 57-69.

Kulawik A., „Bal u Salomona”, czyli Bunt i rezygnacja Hioba, [w:] tegoż, Poezja to jest złoty szerszeń. Rzecz o poematach K. I. Gałczyńskiego, Kraków 2015, s. 45-69.

Kulawik A., „Bal u Salomona” - próba określenia wrażliwości poetyckiej Gałczyńskiego, „Poezja” 1973, nr 12, s. 7-16.

Kulawik A., Serwus, Madonna, czyli Przykrość, jaką zrobiłem Natalii, [w:] tegoż, Poezja to jest złoty szerszeń, Kraków 2014, s. 33-43.

Kulawik A., "Serwus, madonna” Konstantego Ildefonsa Gałczyńskiego, [w:] Literatura polska w szkole średniej, praca zbior. pod red. S. Grzeszczuka, wyd. IV, Warszawa 1990, s. 386-397.

Kwiatkowski J., Literatura Dwudziestolecia, Warszawa 1990.

Lam A., Aluzje literackie, szyfry i cytaty w poezji Gałczyńskiego, [w:] tegoż, Poznać to, co mówimy. Prace filologiczne i wspomnienia, Warszawa 2009, s. 82-92.

Lechoń J., Dziennik, t. I., Londyn 1967.

Lichański S., Poezja Gałczyńskiego, „Pion” 1938, nr 4, s. 4.

Miciński B., Pochylmy się nad wierszami Gałczyńskiego, [w:] Pisma. Eseje. Artykuły. Listy, Kraków 1970, s. 298-304.

Nieukerken A. van, Ironiczny konceptyzm. Nowoczesna polska poezja metafizyczna w kontekście anglosaskiego modernizmu, Kraków 1998.

Ossowski J. S., Sprawa Gałczyńskiego, Kielce 2011.

Ossowski J. S., Szarlatanów nikt nie kocha. Studia i szkice o Gałczyńskim, Kraków 2006. 
Pawłowska-Jądrzyk B., Uczta pod wiszącą skałą. Metafizyczność i nieokreśloność w sztuce (nie tylko) literackiej, Warszawa 2011.

Pogonowska E., Dzikie biesy. Wizja Rosji Sowieckiej w antybolszewickiej poezji polskiej lat 1917-1932, Lublin 2002.

Skarga B., Źródła metafizyczności, [w:] tejże, Kwintet metafizyczny, Kraków 2005, s. 160-196.

Sołtys-Lewandowska E., O „ocalającej nieporządek rzeczy” polskiej poezji metafizycznej i religijnej drugiej polowy XX wieku i początków XXI wieku, Kraków 2015.

Stróżewski W., o metafizyczności w sztuce, [w:] tegoż, Wokół piękna. Szkice z estetyki, Kraków 2002, s. 96-117.

Synowiec J. S., Mędrcy Izraela, ich pisma i nauka, Kraków 1990.

Ślady, zerwania, powroty. Metafizyka i religia w literaturze współczesnej, red. E. Sołtys-Lewandowska, Kraków 2015.

Winniczuk L., Trwałe i aktualne wartości spuścizny naukowej Tadeusza Zielińskiego, [w:] T. Zieliński, Legenda o złotym runie, wybór A. Biernackiego, wstęp J. Krzyżanowskiego, posł. L. Winniczuk, Kraków 1972, s. 361-371.

Wyka K., Poeta i partyjnictwo, [w:] tegoż, Rzecz wyobraźni, wyd. II rozsz., Warszawa 1977, s. 72-77. 